\title{
Profitability effects of financial globalization in an emerging market banking industry: insights into Turkey* $^{*}$
}

\author{
Ece C. Akdoğan ${ }^{1}$ Ekin Ayşe Özşuca ${ }^{2}$
}

\begin{abstract}
The massive financial liberalization followed by accelerating financial globalization leaded to significant structural changes in the financial sector. Since financial institutions play a dominant role in functioning of financial sector, especially in emerging markets where banking industries are generally among the most sensitive sectors to increased interconnectedness of financial markets, how financial globalization actually affects the efficiency of financial intermediation is a vital question. However, although there exists plenty of research focusing on financial integration, impacts of financial globalization is untouched. Hence, this study investigates the bank profitability effects of financial globalization through focusing on an emerging market, Turkey and searches for any potential differences that may prevail among banks with different ownership structures. The findings indicate that while the market based profitability measures improve with financial globalization, the accounting based measures deteriorate pinpointing to an over optimism in the market which in turn brings in mispricing problems. Besides, ownership structure is found to affect the market based measures where banks with domestic and private ownerships are found to benefit more. However, since no significant distinction could be detected among any of the ownership compositions for accounting based profitability measures, such misappraisals seem to foster the optimism in the market.
\end{abstract}

Key words: financial globalization, banking industry, market and accounting based profitability, ownership structure, emerging markets

JEL classification: C23, F61, F65, G21

\footnotetext{
* Received: 11-10-2018; accepted: 14-06-2019

1 Associate Professor, Çankaya University, Department of Banking and Finance, Mimar Sinan Cd. 4, 06790 Ankara, Turkey. Scientific affiliation: managerial finance, financial economics and asset pricing. Phone: +90 31223312 04.Fax: +90 31223310 29. E-mail: ece@cankaya.edu.tr.

2 Assistant Professor, Çankaya University, Department of International Trade, Mimar Sinan Cd. 4, 06790 Ankara, Turkey. Scientific affiliation: financial institutions, macroeconomic theory and monetary policy. Phone: +90 31223312 14. Fax: +90 31223310 29. E-mail: aozsuca@ cankaya.edu.tr (corresponding author).
} 


\section{Introduction}

Financial globalization has been a salient phenomenon in the world recently, as after the profound financial liberalization process in 1980s and 1990s, both advanced and developing countries have witnessed unprecedented levels of crossborder capital flows and they become increasingly integrated into the international financial system, while financial markets become highly interconnected as well. This financial globalization process and its outcomes have come under scrutiny in recent research and policy making agendas. The question of how and through which different channels financial openness influence the economies worldwide has been argued intensively, while both benefits and risks that financial globalization entails for countries have been discussed. Generally speaking, contributing to economic growth and facilitating development of the domestic financial system are put forward as positive consequences of financial globalization, while among the possible risks are increased financial volatility and fragility; exacerbation of the gap between rich and poor.

It is no doubt that financial globalization has brought about significant changes in the structure of the financial sector. As countries remove barriers of entry and allows foreigners to get involved in their domestic banking industry along with the capital markets, their financial markets become increasingly connected to the international financial system. Consequently, this change arising from financial globalization process has distinct implications on both financial system and institutions. As regards with the banking sector, this process results in a widening in the activities of foreign branches as well as an increase in the number of cross-border mergers and acquisitions, particularly from developed countries to developing ones in order to achieve greater market share and higher profit. A bank can expand its operations internationally if it holds processes and other assets that allow it to compete effectively in the foreign markets. These assets constitute foreign bank's competitive advantage over the local rivals which should be substantial enough to offset the costs it incurs in establishing and operating foreign operations. Dunning's eclectic theory (1988), which is deemed to be the standard point of view in the banking literature (Focarelli and Pozzolo, 2001), emphasizes the ownership-specific, location-specific and internalization advantages for explaining the growth in international banking. In that respect, the theory of international banking is heavily based on the theory of foreign direct investment (FDI) (Aliber, 1984). In general, international shareholdings of banks follow the pattern of extending their activities to serve their home-country clients in foreign markets, which may then enable them to build a profound understanding of those markets especially in terms of regulatory and institutional aspects coupled with a developed network with local financial institutiono, leading some of them to provide their services to local population as well (Focarelli and Pozzolo, 2001). 
This increased interconnectedness resulting in a widespread increase in foreign subsidiaries may provide an enlarged opportunity set for financial intermediaries such as additional funds of external finance with lower costs, while higher competition as a result of that deeper integration may pose some challenges for banks in terms of their efficiency as well. Considering the fact that financial institutions play a dominant and significant role in functioning of the financial sector, the question of how the efficiency of financial intermediation change in response to financial globalization has vital importance. In other words, we need to understand whether increased financial globalization yield positive outcomes for banks and help to improve their efficiency. In doing so, bank profitability can be utilized as an informative measure of this efficiency. A clear-cut analysis of financial globalization's impact on bank profitability not only comprehends our understanding about many different facets of globalization, but also has important implications in the sense that it can guide policymakers and regulatory authorities when designing policies to improve efficiency of the industry.

A comprehensive analysis of the link between bank profitability and financial globalization is even more important in an emerging economy context since increasing financial integration with the rest of the world can bring about positive outcomes on the one hand, and could lead to major financial imbalances and severe banking crisis especially for developing countries on the other. Notably, it has been argued in the literature that financial globalization exerts harmful effects on emerging markets making them more vulnerable to crisis. Evidently, banking industries of these countries are the most sensitive sectors in response to this increased interconnectedness of financial markets; hence it requires special attention to assess their financial health in terms of profitability regarding financial globalization process. Along this line, we concentrate on the banking industry in Turkey which provides an ideal case to address this issue for various reasons. First of all, similar to most developing countries, banking industry constitutes a major pillar of the financial system in Turkey and although the operations of foreign banks in the Turkish banking sector are not a new phenomenon, their shares within the Turkish banking sector have initially remained considerably limited. With liberal policies that start being implemented after 1980 in Turkey, just as in the other developing countries, restrictions on capital flows have been abandoned and consequently, the doors of the domestic finance sector have been opened to the outside world. In this respect, with the increasing significance of banking in the Turkish economy and the incentives provided for foreign capital, the entrance of foreign banks into the Turkish banking system has gained momentum after 1980 . During this era, improvements in the foreign capital law, reduction of customs duties and the liberal policies implemented have provided significant incentives for foreign capital inflow leading to a more competitive banking environment. Aftermath, especially following the 2001 economic crisis, Turkish banking sector has undergone through a tremendous restructuring process. As part of the 
"Transition to the Strong Economy Program" that came into effect as of April 2001 and continued until 2004, the Banking Sector Restructuring Program has been implemented resulting in significant improvements in the financial structures of banks. During this period, the sector experienced high growth rates as measured by total assets and improved significantly in terms of productivity, efficiency and capital adequacy. In particular, the ratio of total banking sector assets to GDP reaches to 105 percent, while sector's total assets constitute about 81 percent of the financial system by the end of 2016. Notably, the ratio of bank credits extended to private sector to GDP is realized as approximately 67 percent in the last quarter of 2016, which displays the vital role of bank financing in the Turkish economy. Traditionally, banks have predominated financial intermediation in Turkey, yet many firms do not have access to nonbank funds of external finance. Another noteworthy fact is that a considerable number of foreign banks have raised their shareholdings in the Turkish banking industry beginning from 2005 onwards. The underlying factors behind increased foreign investors' interest in the industry are improved macroeconomic fundamentals and political stability together with increased efficiency of regulation and supervision. As end of 2016, the asset share of foreign owned banks in the total banking sector was nearly 25 percent. During the 2002-2017 period, Turkish banking sector has attracted tremendous amount of FDI, approximately 40 billion dollars, which accounts 78 percent of all the FDI inflow to the Turkish financial sector.

Against this background, this paper investigates the impact of financial globalization on the profitability of Turkish banking industry over the period 2004: Q1-2015: Q4 by utilizing alternative performance indicators. To put differently, it aims to elucidate whether financial globalization enhances or, on the contrary, deteriorates Turkish banking profitability. In particular, disentangling the profitability effects of financial globalization across accounting based versus market based measures enables to gauge market perception about the performance of Turkish banks due to financial globalization over the sample period. The link between financial globalization and profitability is further examined by an ownership breakdown in order to uncover whether this relationship differ with respect to ownership structure. In this respect, following the Dunning's eclectic theory the research is designed to concentrate on the distinction between foreign owned banks versus domestic banks. However, since retail banking is a multi-domestic consumer industry which is imbedded in local law and regulation, banking practices and society in ways that suggest only a few distinctive transferable products in-between well-developed and competitive retail banking markets which are also imitable (Tschoegl, 2002), there exist no reason to expect foreign banks to obtain more benefit in such markets (Tschoegl, 1987; Dufey and Yeung, 1993). On the other hand, in emerging markets, due to the advantages of foreign banks such as large capital, diversification, high expertise, superior ability to diversify risks and the ability to offer services to multinational clients, they may outperform the domestic banks (Dages et al., 2000) 
and may also enjoy new opportunities created by deregulation, transition, and crises (Tschoegl, 2003). In line with those arguments, most of the past empirical evidence point that foreign banks outperform their domestic counterparts in emerging markets (Demirgüc-Kunt and Huizinga, 1999; Claessens et al., 2001; Hasan and Marton, 2003; Lensink and Hermes, 2004; Hermes and Lensink, 2004; Havrylchyk, 2006; Micco et al., 2007; Thi and Venceppa, 2008; Rahman and Reja, 2015) while for developed markets domestic banks are mostly found to perform better than foreign banks (Demirgüc-Kunt and Huizinga, 1999; Berger et al., 2000; Claessens et al., 2001; Micco et al., 2007). Further, through arguing that the managers of government owned banks are less motivated in maximizing profits and are subject to weaker monitoring accompanied with facing softer budget constraints as they receive support from the politicians who in turn demand benefits to their own interest groups and reviewing a survey on the empirical literature examining bank privatization, Megginson (2005) reveals that state-owned banks are less efficient than privately-owned banks, which is also supported by several empirical studies (Berger et al., 2005; Farazi et al., 2011; Jiang et al., 2013; Shaban and James, 2018 ) as well. Following this line of thought, this study further focuses on private/ government distinction. Moreover, effects of some bank specific characteristics and macroeconomic conditions are taken into account.

This paper's contributions to the related literature are expected to be threefold. First of all, to the best of our knowledge, there is no existing study in the literature that investigates the impact of financial globalization on bank profitability. Therefore, this study is the first to address this issue and analyse the link between bank performance and financial globalization for Turkey in particular, and hence provide evidence for emerging market economies in general. Furthermore, it is the first research in the literature that employs the novel KOF Financial Globalization Index for empirical analysis. Finally, unlike the previous studies on bank profitability, market based indicators in addition to accounting based measures are utilized in the econometric analysis to cover the different aspects of bank performance, while controlling for several bank specific characteristics as well. In that way, we can not only assess the extent and the nature of the effects of financial globalization on bank profitability with respect to alternative measures, but also shed light on the main determinants of these accounting based and market based performance measures during the period under investigation. Consequently, this study is specifically designed to question the research hypothesis that "financial globalization fosters bank profitability in terms of both accounting and market based performance measures in emerging markets" through concentrating on Turkish banking industry, and to decompose the main research question of "how globalization impacts the profitability of Turkish banks" by accounting for different ownership structures.

The rest of the paper is organized as follows. Section 2 reviews the related literature, while Section 3 describes the model utilized in the study. Then, Section 
4 provides the empirical data and analysis. After that, Section 5 presents and discusses empirical results and finally, Section 6 concludes the paper.

\section{Literature review}

Globalization is a multifaceted phenomenon which refers to the interconnectedness of a broad range of forces, varying from massive trade liberalization to intensive financial integration or from increased political and socio-cultural interdependence to excessive technological advances. Accordingly, it has been one of the most extensively studied subjects in the literature. Given its widespread scope and multiple dimensions, a vast array of previous research investigates various effects of globalization at macro level considering different channels of which it can influence the economy an, politics along with social and cultural aspects among others $^{3}$. Along this line, most of the earlier literature seems to ignore micro level effects of globalization, while there exiss only a limited number of papers that examine the impact of globalization on banking industry and more specifically, on bank performance. These studies are likely to focus on different components of economic globalization and provide mixed evidence.

The first study in the literature that provides empirical evidence for the impact of economic globalization on bank performance is carried by Sufian and Habibullah (2011). By utilizing frontier based data envelopment methodology, they estimate the efficiency of the Chinese banking sector. According to their results concerning various components of globalization, the impact of higher economic integration, cultural proximity and political globalization seem to be positively related to the efficiency levels of Chinese banks, while the liberalization of capital account is found to have a negative impact. Later, Sufian and Habibullah (2012) examins the link between globalization and performance of Chinese banking sector by controlling for economic, social and political globalization. Their findings suggest that higher economic integration through trade flows, greater social and political globalization exert a positive impact on the Chinese banking sector profitability. Notably, the effect of capital account liberalization is found to work in favour of Chinese banks during the period under investigation. In his analysis of performance impacts of globalization for Nigerian banks, Akinola (2012) finds profit before tax

\footnotetext{
3 for example, see Dreher, 2006; Jamison, Jamison and Hanushek, 2007; Pehnelt, 2007; Leitao, 2011; Rao, Tamazian and Vadlamannati, 2011; Rao and Vadlamannati 2011 on economic factors; Bezemer and Jong-A-Pin, 2008; Dreher, Sturm and Ursprung, 2008; Dreher, Sturm and Vreeland, 2009; Bjornskov and Potrafke, 2011; Chang and Berdiev, 2011 on political issues; Lee and Vivarelli 2006; Dreher and Gaston, 2007 on social notions; De and Pal, 2011; Tsai, 2007 on human development and welfare; Bjornskov, Dreher and Fischer, 2008 on life satisfaction; Vinig and Kluijver, 2007 on entrepreneurial activity; and Lamla, 2009; Gassebner, Gaston and Lamla, 2008 on environmental standards and water pollution, etc.
} 
to be significantly and positively influenced by globalization. As another study on developing countries, by utilizing micro level data on financial institutions, Sufian (2012) analyses globalization effects on net-interest margins of financial sector in Malaysia. The findings of the study show a negative impact of cultural proximity, political globalization and increased economic openness via higher trade volumes on Malaysian financial institutions' net interest margins. A negative and significant impact on margins is further documented for the liberalization of capital accounts. In another study, Zhang and Daly (2014) aim to provide empirical evidence on some determinants of Chinese banking sector performance and their results indicate that higher economic, political and social globalization tend to work in favour of Chinese banks' profitability. For the purpose of examining the effects of various dimensions of globalization on South African banking sector performance, Sufian and Kamarudin (2016) buils an empirical model that takes account multinational banks' origins along with measures of globalization for both home and host countries. Their findings reveal that higher economic globalization and host country's trade flows are positively related with bank profitability, whereas an opposite relationship is detected for the impact of higher social globalization in the host nation. Findings of the study further indicate that banks originating from countries with relatively higher economic globalization tend to have higher profitability levels. On the contrary, banks headquartered in more politically and socially globalized countries seem to perform worse.

As the above review suggests, a straightforward examination of the relationship between financial globalization and banking industry performance seems to be absent in the published literature, which calls for an empirical analysis of that link. In addition to that, there is another strand of literature investigating the impact of financial liberalization on the banking industry. More specifically, substantial number of studies at the international level link financial liberalization to banking industry performance, yet there is relatively a few research focusing on the Turkish case with a nil for financial globalization. Among those studies regarding Turkey, Zaim (1995) analyses the impact of financial liberalization policies on Turkish banking efficiency by applying a nonparametric frontier methodology to commercial banks in both pre- and post- financial reform periods. His results indicate that Turkish banks improve their technical and allocative efficiency following the implementation of financial liberalization programs. Later, Isik and Hassan (2003) investigate the change in total factor productivity of Turkish banks as a result of financial market deregulation during 1981-1990 and find that bank performance has increased significantly in the aftermath of liberalization programs. Yet, Denizer et al. (2007), who analyse Turkish banking efficiency in pre- and postfinancial liberalization eras covering the years from 1970 to 1994, conclude that there is considerable reduction in the efficiency of Turkish banks following the liberalization process. However, it is important to note that our paper significantly diverges from the above-referred studies in the previous literature that investigate 
the relationship between financial sector liberalization and bank performance in Turkey, since we are interested in the impact of financial globalization on the profitability of Turkish banking industry, on which there appears to be a lack of empirical research.

\section{The model}

This study aims to investigate the impact of financial globalization on the profitability of Turkish banks. For this purpose, the profitability effects of financial globalization, which is measured by the KOF Financial Globalization Index, are investigated through focusing not only on accounting based profitability measures but also on market based performance measures which will enable to get a deeper insight. In this respect, this study utilizes return on assets (ROA), operating return on assets (OROA) and net interest margin (NIM) as accounting based profitability measures, while stock returns (R) and Tobin's Q (TQ) are used as measures of market based profitability.

The impact of financial globalization on the profitability of Turkish banks is investigated by using pooled panel analyses ${ }^{4}$ with quarterly data. The sample consists BIST (Borsa Istanbul) listed banks that are actively being traded during the research period of 2004: Q1-2015: Q4. However, since KOF Globalization Indices are constructed on annual basis, the Financial Globalization Index is converted into quarterly dataset by using Cubic Spline Interpolation. Besides, bank specific variables of size, liquidity and capital adequacy are also included in the model as control variables along with real GDP growth rate and two dummy variables to account for general economic conditions and varying ownership structures, i.e. government and foreign ownership, leaving us with the five versions of the model below:

$$
Y_{i, t}=\beta_{1} F G_{\mathrm{t}}+\beta_{2} S_{i, t}+\beta_{3} C_{i, t}+\beta_{4} L_{i, t}+\beta_{5} G D P g r_{t}+\beta_{6} D_{g}+\beta_{7} D_{f}+\epsilon
$$

where $\mathrm{Y}$ denotes the profitability measures, specifically ROA, NIM, OROA, R and TQ. FG, S, C, L, $\mathrm{D}_{\mathrm{g}}$ and $\mathrm{D}_{\mathrm{f}}$ represent the financial globalization index, size, capital adequacy, liquidity, government and foreign ownership dummies respectively.

For the models the dummy variable(s) is/are found to be significant, to search for the prevailing differences in the profitability effects of financial globalization among banks with different ownership compositions, the sample is subdivided into

$\overline{4}$ To determine the most appropriate panel model, F-test is applied to test for fixed effects, while Breusch and Pagan's (1980) Lagrange Multiplier (LM) test is conducted for random effects. As the null hypotheses are not rejected in either case, the pooled OLS is favored. 
two, twice where the first distinction is based on government/private ownership and the second on domestic/foreign ownership. Then the above model is adjusted by subdividing the financial globalization index accordingly which brings in the additional versions of the two models below:

$$
\begin{aligned}
& Y_{i, t}=\beta_{1} F G g_{t}+\beta_{2} F G p_{t}+\beta_{3} S_{i, t}+\beta_{4} C_{i, t}+\beta_{5} L_{i, t}+\beta_{6} G D P g r_{t}+\beta_{7} D_{g}+\beta_{8} D_{f}+\epsilon \\
& Y_{i, t}=\beta_{1} F G d_{t}+\beta_{2} F G f_{t}+\beta_{3} S_{i, t}+\beta_{4} C_{i, t}+\beta_{5} L_{i, t}+\beta_{6} G D P g r_{t}+\beta_{7} D_{g}+\beta_{8} D_{f}+\epsilon
\end{aligned}
$$

where $\mathrm{FG}_{\mathrm{g}}-\mathrm{GF}_{\mathrm{p}}$ and $\mathrm{FG}_{\mathrm{d}}-\mathrm{FG}_{\mathrm{f}}$ denote the distinction on government-private ownership and domestic-foreign ownership respectively.

\section{Empirical data and analysis}

The profitability effects of financial globalization in Turkish banking industry are searched for via pooled panel analyses through utilizing the models above by using individual bank level quarterly data for the period 2004: Q1-2015: Q4. In the analyses, along with various explanatory variables namely the financial globalization index, size, liquidity, capital adequacy and real GDP growth rate, five profitability measures are employed among which three of them, specifically the return on assets, operating return on assets and net interest margin, represent accounting based profitability measures while the remaining two, particularly the stock returns and Tobin's Q, address market based profitability. Besides, the analyses are further conducted to examine whether the profitability effects of globalization vary among different ownership structures by incorporating public/private and domestic/foreign dummy variables into the specification. The information on the data used in the analyses and the empirical findings are respectively provided next.

\subsection{Empirical data}

The data on the closing price of bank stocks, operating income, total assets and TQ are extracted from Bloomberg while ROA, NIM and liquidity are sourced from Banks Association of Turkey. Real GDP growth rate is obtained from OECD Economic Outlook database.

Regarding the profitability measures, the stock returns are calculated as the percentage change in the quarterly closing stock prices, OROA is found by dividing operating income to total assets, ROA indicates the return on assets and NIM is measured as the net income to total assets ratio. As standard bank specific control variables in the literature, liquidity, capitalization and bank size are calculated as follows: liquidity is expressed by the ratio of liquid assets to total assets, 
capitalization is measured by the ratio of shareholders' equity to total assets, bank size is the natural logarithm of total assets. The dummy variables are determined through investigating the ownership structures of the banks in the sample.

As being the key measure of our analysis, the degree of financial globalization is measured by using KOF Financial Globalization Index, a newly released subindex of 2018 version of KOF Globalization Index. KOF Globalization Index which is originally developed by Dreher (2006), updated in Dreher et al. (2008) and provided by Swiss Federal Institute of Technology, provides a highly composite indicator of globalization through combining various variables that measure different aspects of globalization into one final index, and as put by Potrafke (2015), has become the most widely used globalization index in the literature. The original version of the Index measures globalization along the economic, social and political dimensions for almost every country since 1970 and provides sub-indices on each dimension as well. In 2018, it is revised by Gygli et al. (2018) which brought in important revisions such as enrichment in the sub-indices provided along with an increase in the total number of underlying variables. In this context, through introducing a differentiation between trade and financial globalization within the economic dimension of globalization, the 2018 version of KOF Globalization Index also enables the launch of new sub-indices, specifically the Trade and the Financial Globalization Indices. The Financial Globalization Index is composed by combining data on foreign direct investment, portfolio investment, international debt, international reserves and international income payments which are obtained from IMF database and are expressed as a percentage of GDP. Besides, allowing the weights of the underlying variables to vary over time serves as another important new feature of 2018 KOF Globalization Indices that may worth mentioning.

Description of the variables and sources are presented in Table 1 and summary statistics are provided in Table 2. 
Ece C. Akdoğan, Ekin Ayşe Özşuca • Profitability effects of financial globalization...

Zb. rad. Ekon. fak. Rij. $\cdot 2019 \cdot$ vol. $37 \cdot$ no. $1 \cdot 303-325$

Table 1: Description of variables and sources

\begin{tabular}{|c|c|c|c|}
\hline Variable & Notation & Description & Source \\
\hline Return on Assets & $\mathrm{ROA}$ & $\begin{array}{l}\text { The ratio of net profit to total } \\
\text { assets }\end{array}$ & $\begin{array}{l}\text { Banks Association of } \\
\text { Turkey }\end{array}$ \\
\hline Net Interest Margin & NIM & $\begin{array}{l}\text { The ratio of net interest income to } \\
\text { total assets }\end{array}$ & $\begin{array}{l}\text { Banks Association of } \\
\text { Turkey }\end{array}$ \\
\hline $\begin{array}{l}\text { Operating Return on } \\
\text { Assets }\end{array}$ & OROA & $\begin{array}{l}\text { The ratio of operating income to } \\
\text { total assets }\end{array}$ & Bloomberg \\
\hline Stock Returns & $\mathrm{R}$ & $\begin{array}{l}\text { The percentage change in the } \\
\text { quarterly closing stock prices }\end{array}$ & Bloomberg \\
\hline Tobin's Q & TQ & $\begin{array}{l}\text { The ratio of market value of the } \\
\text { company to the replacement value } \\
\text { of the firm's assets. }\end{array}$ & Bloomberg \\
\hline \begin{tabular}{|l|} 
Financial \\
Globalization \\
\end{tabular} & FG & The financial globalization index & Dreher et al. (2008) \\
\hline Size & $\mathrm{S}$ & Log of total assets (million) & $\begin{array}{l}\text { Banks Association of } \\
\text { Turkey }\end{array}$ \\
\hline Capitalization & $\mathrm{C}$ & $\begin{array}{l}\text { The ratio of shareholders' equity to } \\
\text { total assets }\end{array}$ & $\begin{array}{l}\text { Banks Association of } \\
\text { Turkey }\end{array}$ \\
\hline Liquidity & $\mathrm{L}$ & $\begin{array}{l}\text { The ratio of liquid assets to total } \\
\text { assets }\end{array}$ & $\begin{array}{l}\text { Banks Association of } \\
\text { Turkey }\end{array}$ \\
\hline Real GDP & GDPgr & $\begin{array}{l}\text { Quarter-on- quarter changes in real } \\
\text { GDP (1998 constant prices) }\end{array}$ & OECD Economic Outlook \\
\hline Government Dummy & $\mathrm{D}_{\mathrm{g}}$ & $\begin{array}{l}\text { Dummy variable for government } \\
\text { ownership }\end{array}$ & $\begin{array}{l}\text { Banks Association of } \\
\text { Turkey }\end{array}$ \\
\hline Foreign Dummy & $\mathrm{D}_{\mathrm{f}}$ & $\begin{array}{l}\text { Dummy variable for foreign } \\
\text { ownership }\end{array}$ & $\begin{array}{l}\text { Banks Association of } \\
\text { Turkey }\end{array}$ \\
\hline
\end{tabular}

Source: Authors' research

Table 2: Summary statistics

\begin{tabular}{|l|c|r|r|r|r|}
\hline \multicolumn{1}{|c|}{ Variable } & Observations & \multicolumn{1}{c|}{ Mean } & \multicolumn{1}{c|}{ Std. Dev. } & \multicolumn{1}{c|}{ Min. } & \multicolumn{1}{c|}{ Max. } \\
\hline ROA & 576 & 1.4779 & 1.7442 & -12.5543 & 18.7619 \\
\hline NIM & 576 & 2.3220 & 1.2639 & 0.5158 & 8.8348 \\
\hline OROA & 529 & 0.0069 & 0.0115 & -0.1143 & 0.2182 \\
\hline R & 551 & 0.0584 & 0.2407 & -0.6389 & 1.2564 \\
\hline TQ & 526 & 1.0838 & 0.1569 & 0.8885 & 2.4856 \\
\hline S & 576 & 10.0964 & 1.5773 & 6.1244 & 12.5423 \\
\hline C & 576 & 14.5360 & 10.1303 & 5.9272 & 75.7109 \\
\hline L & 576 & 29.2130 & 9.6067 & 5.8281 & 52.8081 \\
\hline GDPgr & 576 & 1.4208 & 2.1290 & -5.1000 & 5.5000 \\
\hline
\end{tabular}

Source: Authors' calculations 


\subsection{Empirical analysis}

As the first step of the empirical analysis, panel stationarity tests are carried out to data in levels to identify whether the variables have unit root or not. Accordingly, the stationarity results related to all bank-specific variables through the application of Levin-Lin-Chu (LLC) (Levin et al., 2002), Im-Pesaran-Shin (IPS) (Im et al.,2003), Fisher-type Augmented Dickey-Fuller and Phillips- Perron (PP) (Maddala and $\mathrm{Wu}, 1999$; Choi, 2001) tests are displayed in Table 3. The panel unit root tests reject the presence of non-stationarity for all variables, implying that they are stationary. ${ }^{5}$

Table 3: Panel unit root tests

\begin{tabular}{|l|c|c|c|c|c|c|c|c|}
\hline \multirow{2}{*}{$\begin{array}{c}\text { Null: } \\
\text { Unit root }\end{array}$} & \multicolumn{2}{|c|}{ LLC } & \multicolumn{2}{c|}{ Fisher ADF } & \multicolumn{2}{c|}{ Fisher PP } & \multicolumn{3}{c|}{ IPS } \\
\cline { 2 - 10 } & $\begin{array}{c}\text { assumes common } \\
\text { unit root }\end{array}$ & \multicolumn{5}{c|}{ assumes individual unit root process } \\
\hline Series & Statistic & Prob. & Statistic & Prob. & Statistic & Prob. & Statistic & Prob. \\
\hline ROA & -11.0027 & 0.0000 & 199.224 & 0.0000 & 220.160 & 0.0000 & -12.7445 & 0.0000 \\
\hline NIM & -17.3305 & 0.0000 & 318.987 & 0.0000 & 322.332 & 0.0000 & -19.1930 & 0.0000 \\
\hline OROA & -6.72356 & 0.0000 & 111.038 & 0.0000 & 235.111 & 0.0000 & -7.70136 & 0.0000 \\
\hline R & -11.3598 & 0.0000 & 170.334 & 0.0000 & 296.342 & 0.0000 & -11.2679 & 0.0000 \\
\hline TQ & -2.75916 & 0.0029 & 38.8255 & 0.0285 & 36.4813 & 0.0493 & -2.37638 & 0.0087 \\
\hline S & -5.47053 & 0.0000 & 66.5588 & 0.0000 & 51.1829 & 0.0010 & -3.76551 & 0.0001 \\
\hline C & -2.19843 & 0.0140 & 49.7674 & 0.0015 & 59.6798 & 0.0001 & -3.42800 & 0.0003 \\
\hline L & -2.69489 & 0.0035 & 41.5522 & 0.0145 & 48.6664 & 0.0021 & -2.02993 & 0.0212 \\
\hline
\end{tabular}

Note: Probabilities for Fisher tests are computed using an asymptotic Chi-square distribution. All other tests assume asymptotic normality.

Source: Authors' calculations

The estimation results obtained for the whole sample (Eq. 1) are provided in Table 4.

\footnotetext{
5 Furthermore, identification tests are applied for each specification before interpreting the results of the empirical models. In that respect, the White test for heteroscedasticity, Jarque-Bera test for normality and Lagrange Multiplier (LM) test for autocorrelation are performed. Overall, the results of these tests suggest that error terms are normally distributed and there is no problem of autocorrelation and heteroscedasticity in the models.
} 
Table 4: Panel analysis results for the whole sample

\begin{tabular}{|c|c|c|c|c|c|}
\hline Exp.var. & $\begin{array}{l}\text { Model } 1 \\
\text { (ROA) }\end{array}$ & $\begin{array}{l}\text { Model } 2 \\
\text { (OROA) }\end{array}$ & $\begin{array}{l}\text { Model } 3 \\
\text { (NIM) }\end{array}$ & $\begin{array}{l}\text { Model } 4 \\
\text { (R) }\end{array}$ & $\begin{array}{l}\text { Model } 5 \\
\text { (TQ) }\end{array}$ \\
\hline FG & $\begin{array}{r}-0.0314 * * * \\
(-3.4288)\end{array}$ & $\begin{array}{l}-0.0001 * \\
(-1.8106)\end{array}$ & $\begin{array}{r}-0.0314 * * * \\
(-3.4288)\end{array}$ & $\begin{array}{r}0.0031 * * \\
(2.2349)\end{array}$ & $\begin{array}{r}0.0116^{* * * *} \\
(15.6119)\end{array}$ \\
\hline $\mathrm{S}$ & $\begin{array}{r}0.2085^{* * *} * \\
(3.4837)\end{array}$ & $\begin{array}{l}0.0007 \\
(1.555)\end{array}$ & $\begin{array}{r}0.2085^{* * *} * \\
(3.4837)\end{array}$ & $\begin{array}{r}-0.0136 \\
(-1.4682) \\
\end{array}$ & $\begin{array}{r}-0.0022 \\
(-0.4528) \\
\end{array}$ \\
\hline $\mathrm{L}$ & $\begin{array}{r}0.0138^{*} \\
(1.822)\end{array}$ & $\begin{array}{r}0.0001 * * \\
(2.1971)\end{array}$ & $\begin{array}{c}0.0138^{*} \\
(1.8221)\end{array}$ & $\begin{array}{r}0.0005 \\
(0.3519)\end{array}$ & $\begin{array}{r}0.0038^{* * * *} \\
(5.951)\end{array}$ \\
\hline $\mathrm{C}$ & $\begin{array}{r}0.0789 * * * \\
(8.601) \\
\end{array}$ & $\begin{array}{r}0.0003 * * * \\
(4.4564)\end{array}$ & $\begin{array}{r}0.0789 * * * \\
(8.601) \\
\end{array}$ & $\begin{array}{r}0.0005 \\
(0.3628) \\
\end{array}$ & $\begin{array}{r}0.011 * * * \\
(13.8515) \\
\end{array}$ \\
\hline GDPgr & $\begin{array}{r}0.0368 \\
(-1.1897) \\
\end{array}$ & $\begin{array}{r}4.25 \mathrm{E}-05 \\
(0.1892) \\
\end{array}$ & $\begin{array}{r}-0.0368 \\
(-1.1897) \\
\end{array}$ & $\begin{array}{r}0.0013 \\
(0.2775) \\
\end{array}$ & $\begin{array}{r}0.008 * * * \\
(3.393) \\
\end{array}$ \\
\hline $\mathrm{Dg}$ & $\begin{array}{r}0.1096 \\
(0.5813)\end{array}$ & $\begin{array}{r}-0.0002 \\
(-0.1644) \\
\end{array}$ & $\begin{array}{r}0.1096 \\
(0.5813)\end{array}$ & $\begin{array}{r}-0.0778 * * \\
(-2.5064)\end{array}$ & $\begin{array}{r}0.0557 * * * \\
(3.5587)\end{array}$ \\
\hline Df & $\begin{array}{r}-0.0185 \\
(-0.1116) \\
\end{array}$ & $\begin{array}{r}-0.0005 \\
(-0.4145) \\
\end{array}$ & $\begin{array}{l}-0.0185 \\
(-0.111) \\
\end{array}$ & $\begin{array}{r}-0.0584^{* *} \\
(-2.3097) \\
\end{array}$ & $\begin{array}{r}0.0529 * * * \\
(4.2698) \\
\end{array}$ \\
\hline $\mathrm{R}^{2}$ & 0.5902 & 0.4805 & 0.5902 & 0.4278 & 0.6553 \\
\hline
\end{tabular}

Notes: $t$-statistics are presented in parentheses. $* * * * * *$ denote statistical significance at $1 \%, 5 \%$ and $10 \%$ levels, respectively.

Source: Authors' calculations

As Table 4 reveals, the findings obtained from Model 1 through 5 suggest that financial globalization significantly affects profitability of Turkish banks: $\mathrm{R}$ and TQ are found to increase with financial globalization at significance levels of 5\% and $1 \%$ respectively while ROA, OROA and NIM are found to decrease with $1 \%$, $10 \%$ and $1 \%$ significance levels respectively. Thus, although financial globalization is found to have a significant impact on bank profitability, the findings indicate a negative impact on accounting based profitability measures while a positive impact is reported for market based profitability measures. On the other hand, the market is also found to account for the ownership composition of banks. Both the government and the foreign ownership dummies are found to be significant at $5 \%$ significance levels for stock returns and at $1 \%$ significance levels for TQ, while for accounting based performance measures none of the dummies are reported to be significant at conventional levels. Thus, to search for the prevailing differences among the sub-sampled groups of banks, we proceed with Eq. 2 and 3 for the market based profitability measures of R and TQ, and the results are summarized in Table 5. 
Table 5: Panel Analysis Results for Sub-Samples

\begin{tabular}{|c|c|c|c|c|}
\hline Exp.var. $\quad$ Models & $\begin{array}{l}\text { Model } 6 \\
(\mathrm{R})\end{array}$ & $\begin{array}{l}\text { Model } 7 \\
\text { (TQ) }\end{array}$ & $\begin{array}{l}\text { Model } 8 \\
(\mathrm{R})\end{array}$ & $\begin{array}{l}\text { Model } 9 \\
\text { (TQ) }\end{array}$ \\
\hline $\mathrm{FGg}$ & $\begin{array}{l}0.003 * * \\
(2.1693)\end{array}$ & $\begin{array}{r}0.0116^{* * *} \\
(15.7569)\end{array}$ & & \\
\hline FGp & $\begin{array}{r}0.0035^{* *} \\
(2.3608) \\
\end{array}$ & $\begin{array}{r}0.0126 * * * \\
(15.9542)\end{array}$ & & \\
\hline FGd & & & $\begin{aligned} 0.003 * * \\
(2.1681) \\
\end{aligned}$ & $\begin{array}{r}0.0107 * * * \\
(15.736) \\
\end{array}$ \\
\hline FGf & & & $\begin{array}{l}-0.0007 \\
(-0.067) \\
\end{array}$ & $\begin{array}{r}-0.034 * * * \\
(-7.8673) \\
\end{array}$ \\
\hline $\mathrm{S}$ & $\begin{array}{r}-0.0154 \\
(-1.6111)\end{array}$ & $\begin{array}{l}-0.0072 \\
(-1.451)\end{array}$ & $\begin{array}{l}-0.013 \\
(-1.38)\end{array}$ & $\begin{array}{r}0.006 \\
(1.3387)\end{array}$ \\
\hline L & $\begin{array}{r}0.0005 \\
(0.3929) \\
\end{array}$ & $\begin{array}{r}0.0039 * * * \\
(6.2256) \\
\end{array}$ & $\begin{array}{r}0.0004 \\
(0.2919) \\
\end{array}$ & $\begin{array}{r}0.0029 * * * \\
(4.963) \\
\end{array}$ \\
\hline $\mathrm{C}$ & $\begin{array}{r}0.0004 \\
(0.2542) \\
\end{array}$ & $\begin{array}{r}0.011 * * * \\
(13.213) \\
\end{array}$ & $\begin{array}{r}0.0006 \\
(0.4049) \\
\end{array}$ & $\begin{array}{r}0.0119^{* * *} \\
(16.4156) \\
\end{array}$ \\
\hline GDPgr & $\begin{array}{r}0.0013 \\
(0.2626)\end{array}$ & $\begin{array}{r}0.008^{* * *} \\
(3.413) \\
\end{array}$ & $\begin{array}{r}0.0014 \\
(0.2914)\end{array}$ & $\begin{array}{r}0.0088^{* * *} \\
(4.1068) \\
\end{array}$ \\
\hline $\mathrm{Dg}$ & $\begin{array}{l}-0.0525 \\
(-1.158) \\
\end{array}$ & $\begin{array}{r}0.1128 * * * \\
(4.9995) \\
\end{array}$ & $\begin{array}{r}-0.0787 * * \\
(-2.5265) \\
\end{array}$ & $\begin{array}{r}0.0441 * * * \\
(3.1033) \\
\end{array}$ \\
\hline Df & $\begin{array}{r}-0.0643 * * \\
(-2.4311)\end{array}$ & $\begin{array}{r}0.039 * * * \\
(3.0298)\end{array}$ & $\begin{array}{r}0.1959 \\
(0.3012)\end{array}$ & $\begin{array}{r}3.1234 * * * \\
(10.8557)\end{array}$ \\
\hline $\mathrm{R}^{2}$ & 0.4289 & 0.6677 & 0.4281 & 0.7536 \\
\hline
\end{tabular}

Notes: $\mathrm{t}$-statistics are presented in parentheses. $* * *, * * *$ denote statistical significance at $1 \%, 5 \%$ and $10 \%$ levels, respectively.

Source: Authors' calculations

The findings of Model 6 and 7 indicate that the stock returns and Tobin's Q of both governmentally and privately owned banks increase with financial globalization at $5 \%$ and $1 \%$ significance levels respectively. However, although the stock market based performance measures of both groups of banks are found to improve with financial globalization significantly, the impact on private banks is observed to be stronger. On the other hand, the findings obtained from Model 8 show that financial globalization significantly rises the stock market returns of domestically owned banks with 5\% significance level while the results lack to provide a significant impact on banks with foreign affiliation. But, though statistically not significant, the findings demonstrate a negative impact of financial globalization on the stock returns of foreign affiliated banks. As the results for TQ are considered (Model 9), consistent with the findings of Model 8, TQ of domestically owned banks are also found to rise with financial globalization at $1 \%$ significance level while TQ of foreign affiliated banks are found to decrease as financial globalization increases with $1 \%$ significance level. Thus, when the domestic/foreign ownership is accounted, the results show a positive impact on domestically owned banks and a negative impact on foreign affiliated banks. 


\section{Results and discussion}

An overall evaluation of the analyses results indicates that financial globalization significantly affects the profitability of BIST listed banks. However, while this impact is found to be positive in terms of market based performance measures of $\mathrm{R}$ and TQ, it is reported to be negative for accounting based profitability measures of ROA, OROA and NIM. This adverse impact on the accounting based profitability measures is probably due to the increased competition fostered by deepening financial globalization and the favorable impact on market based profitability measures probably reflects the over optimism in the market about the future prospects of banks with regard to financial globalization. Besides, considering that the ownership concentration of banks in Turkey, like in most of the emerging economies, are quite high, another partial explanation for these conflicting results obtained for accounting- and market-based performance measures can be provided by the argument that higher ownership concentration leads to better market performance but a lower accounting performance (Gürsoy and Aydoğan, 2002). On the other hand, the ownership composition of banks is found to be significant for market based profitability measures while no statistically significant impact could be reported for accounting based performance measures. Thus, although the market expects financial globalization to have differing impacts among banks with different ownership compositions, the reported results of bank's operations provided by their financial statements lack to provide support for this expectation. Nevertheless, to understand in which ways the market's assessment differs among banks with different ownership compositions, the analyses are further proceeded and it is found that the positive impact on the market based performance measures mainly reflects the favorable impact on domestically owned banks, whether with government or private ownership, since the impact on foreign affiliated banks are found to be negative. This negative impact can be argued to stem from the possibility that financial globalization causes deterioration in the competitive advantage of foreign affiliated banks. Due to spillover and monitoring effects, it is argued that, owing a foreign affiliation is expected to reduce bank risks and to provide advanced management knowledge and external financing (Aggarwal et al., 2011; Zhu and Yang, 2016; Cheng et al., 2016). Besides, foreign affiliated banks can attain an easier access to international funding sources and can obtain better terms through the use of internal capital markets. However as financial globalization facilitates the integration of financial markets and reduces the barriers, domestically owned banks will also capture benefits from easier access to international sources of funds which in turn will weaken the relative competitive advantage of foreign affiliated banks, and thus have an adverse impact on their profitability. In other words, foreign banks start losing their pre-enjoyed benefits with an accompanying improvement in the efficiencies of domestic banks, and given that the efficiency of Turkish banking sector has been strongly improved through the Banking Sector Restructuring Program which has been completed before the period under consideration jointly 
provide a plausible explanation. However, such an effect is found to be valid only for market based profitability measures as no significant difference could be reported in-between the domestically owned and foreign affiliated banks for accounting based profitability measures, which raises questions on the actual validity of such a distinction between these two groups of banks in Turkey based on such reasoning, and points to a possible misappraisal in the market. Thus it can be concluded that the market is overoptimistic about the consequences of financial globalization on the prospective performances of domestically owned banks leading to a possible misappraisal of their shares. Besides, the findings also show that the privately owned banks benefit more from financial globalization in terms of market based profitability measures indicating that the market expects private banks to benefit more from financial globalization. This may be a reflection of a widely debated belief that private banks operate more efficiently and effectively than governmentowned banks. But since no significant distinction could be detected among any of the ownership compositions in terms of accounting based performance measures, it is not possible to conclude the findings as providing support for this argument.

\section{Conclusion}

The massive financial liberalization of 1980s and 1990s followed by an accelerating process of financial globalization that leads to significant structural changes in the financial sector have come under scrutiny in recent research and policy making agendas. Particularly since 2000s, both developed and developing countries have witnessed unprecedented levels of cross-border capital flows and they become increasingly integrated into the international financial system, while national financial markets become progressively interconnected as well. On the other hand, given that financial institutions play a significant dominant role in the functioning of financial sectors, how financial globalization actually affects the efficiency of financial intermediation remains as a vital question. Besides, it has been widely argued in the literature that financial globalization exerts harmful effects on emerging markets making them more vulnerable to economic and banking crisis. Considering the dominant role of the banking sector within the financial intermediation services of most of the emerging countries including Turkey, a comprehensive analysis of the link between bank profitability and financial globalization proves to be even more important in an emerging economy context since increasing financial integration with the rest of the world can bring in positive outcomes or lead to major financial imbalances and severe banking crisis. However, although there exist a wide array of research focusing on financial integration with a handful research concentrating on different dimensions of globalization, the impacts of financial globalization are untouched. Thus, in an attempt to fulfil this gap, this study is aimed at investigating the bank profitability effects of financial globalization through focusing on an emerging market, Turkey and searching for any potential differences that may 
prevail among banks with regard to different ownership structures. The findings of the study indicate that financial globalization, contrary to the research hypothesis, has a significant negative impact on accounting based profitability measures which may arise from squeezed profit margins as a result of increased competition fostered by deepening financial globalization while, in line with the research hypothesis, a significant positive effect is reported for market based performance measures, and thus signaling an over optimism in the market. Besides, a breakdown for ownership compositions pinpoints that this positive impact on the market based performance measures seems to reflect the favorable impact on domestically owned banks, whether with government or private ownership, since the findings, in fact, demonstrate a negative effect of financial globalization on the market based profitability measures of foreign affiliated banks. This adverse impact can arise due to a weakening in the competitive advantage of foreign affiliated banks as domestically owned banks will promptly capture benefits from easier access to international sources of funds since financial globalization facilitates the integration of financial markets and reduces the barriers. Besides, the privately owned banks are found to benefit more from financial globalization in terms of market based profitability measures compared to their government-owned counterparts. Although this result can be regarded as providing support for the view that private banks operate more efficiently and effectively than government-owned banks, its actual validity is flue since the results for accounting profitability measures lack to support significant differences among banks with different ownership structures. In sum, an overall examination of the analysis results leads to the comparative conclusion that while financial globalization deteriorates the accounting profitability, it enhances the market based profitability where this positive effect mainly comes through the domestic banks. Thus it can be concluded that the market is overoptimistic about the consequences of financial globalization on the prospective performances of domestically owned banks leading to a possible misappraisal of their shares which in turn seems to foster the optimism in the market. Given the argument that globalization acts as a two-edged sword that can be both beneficial and detrimental to businesses and considering the overwhelming process of globalization, it is apparent that more research focusing on the profitability and efficiency impacts of globalization are vitally needed. In this respect, it would be worthy for future research to extend the impacts of financial globalization on some other bank specific factors. In this respect, liquidity stands as an important individual aspect to be further investigated. Besides, prospective studies can also focus on different financial institutions like insurance companies as well as on other industries. Additionally, since this study is specifically designed to investigate the profitability effects of financial globalization on bank performance with a special focus on ownership breakdowns to search for any differences that may potentially prevail among differing ownership structures, the distinction among foreign banks based on entry forms and modes along with country and location specific effects are out of the scope of this study. However, it would be interesting for future research to account for such factors in analyzing the research topic, especially those with a special focus on 
foreign banks and/or banking FDI. Besides, as the ownership breakdown in this study is based solely on the control rights, the incremental changes in ownership structure without causing a change in control may turn out to be masked which would be a challenging research topic for future research as well. Finally, the impacts of other dimensions of globalization such as social and political globalizations can also be examined.

\section{References}

Aggarwal, R. et al. (2011) "Does governance travel around the world? Evidence from institutional investors", Journal of Financial Economics, Vol. 100, pp. 154-181, doi: 10.1016/j.jfineco.2010.10.018.

Akinola, G. O. (2012) "Effect of Globalization on Performance in the Nigerian Banking Industry", International Journal of Management and Marketing Research, Vol. 1, No. 5, pp. 79-94.

Aliber, Z. R. (1984) "International Banking: A Survey", Journal of Money, Credit, and Banking, Vol. 16, No. 4, pp. 661-678, doi: 10.2307/1992100.

Berger, A. N. et al. (2000) "Globalization of Financial Institutions: Evidence from Cross-Border Banking Performance", Brookings-Wharton Papers on Financial Services, Vol. 2000, No. 1, pp. 23-120, doi: 10.1353/pfs.2000.0001.

Berger, A.N. et al. (2005) "Corporate governance and bank performance: A joint analysis of the static, selection, and dynamic effects of domestic, foreign, and state ownership", Journal of Banking \& Finance, Vol. 29, No. (8-9), pp. 2179 2221, doi: 10.1016/j.jbankfin.2005.03.013.

Bezemer, D., Jong-A-Pin, R. (2008) "World on Fire? Democracy, Globalization and Ethnic Violence" MPRA paper number 7027, Available at: $<$ https://mpra.ub. uni-muenchen.de/7027/1/MPRA_paper_7027.pdf>.

Bjornskov, C., Dreher, A., Fischer, J. A.V. (2008) "Cross-Country Determinants of Life Satisfaction: Exploring Different Determinants across Groups in Society", Social Choice and Welfare, Vol. 30, No. 1, pp. 119-173, doi: 10.1007/s00355007-0225-4.

Bjornskov, C., Potrafke, N. (2011) "Politics and Privatization in Central and Eastern Europe: A Panel Data Analysis", Economics of Transition, Vol. 19, No. 2, pp. 201-230, doi: 10.1111/j.1468-0351.2010.00404.x.

Breusch, T.S., Pagan, A.R. (1980) "The Lagrange Multiplier Test and Its Applications to Model Specification in Econometrics", The Review of Economic Studies, Vol. 47, No. 1, pp. 239-253, doi: 10.2307/2297111.

Chang, C.P., Berdiev, A. N. (2011) "The Political Economy of Energy Regulation in OECD Countries", Energy Economics, Vol. 33, No. 5, pp. 816-825, doi: 10.1016/j.eneco.2011.06.001. 
Cheng, M., Hongyan Geng, H., Zhang, J. (2016) "Chinese commercial banks: Benefits from foreign strategic investors?", Pacific-Basin Finance Journal, Vol. 40, pp. 147-172, doi: 10.1016/j.pacfin.2016.10.011.

Choi, I. (2001) "Unit root tests for panel data", Journal of International Money and Finance, Vol. 20, No. 2, pp. 249-272, doi: 10.1016/s0261-5606(00)00048-6.

Claessens, S., Demirgüç-Kunt, A., Huizinga, H. (2001) "How does foreign entry affect domestic banking markets?", Journal of Banking \& Finance, Vol. 25, No. 5, pp. 891-911, doi: 10.1016/s0378-4266(00)00102-3.

Dages, B. G., Linda, G., Kinney, D. (2000) "Foreign and domestic bank participation in emerging markets: Lessons from Mexico and Argentina", Federal Reserve Bank of New York Economic Policy Review, pp. 17-36.

De, U. K., Pal, M. (2011) "Dimensions of globalization and their effects on economic growth and human development index", Asian Economic and Financial Review, Vol. 1, No. 1, pp. 1-13.

Demirgüç-Kunt, A., Huizinga, H. (1999) "Determinants of Commercial Bank Interest Margins and Profitability: Some International Evidence", World Bank Economic Review, Vol. 13, No. 2, pp. 379-408, doi: 10.1093/wber/13.2.379.

Denizer, C. A., Dinc, A., Tarimcilar, M. (2007) "Financial liberalization and banking efficiency: evidence from Turkey", Journal of Productivity Analysis, Vol. 27, No. 3, pp. 177-195, doi: 10.1007/s11123-007-0035-9.

Dreher, A. (2006) "Does Globalization Affect Growth? Evidence from a New Index of Globalization", Applied Economics, Vol. 38, No. 10, pp. 1091-1110, doi: 10.1080/00036840500392078.

Dreher, A., Gaston, N. (2007) "Has globalization really had no effect on unions?", Kyklos, Vol. 60, pp. 165-186, doi: 10.1111/j.1467-6435.2007.00367.x.

Dreher, A., Gaston, N., Martens, P. (2008) Measuring Globalization - Gauging its Consequences, New York: Springer.

Dreher, A., Sturm, J. E., Ursprung, H.W. (2008) "The Impact of Globalization on the Composition of Government Expenditures Evidence from Panel Data", Public Choice, Vol. 134, No. 3, pp. 263-292, doi: 10.1007/s11127-007-9223-4

Dreher, A., Sturm, J. E., Vreeland, J. R. (2009) "Development Aid and International Politics: Does Membership on the UN Security Council Influence World Bank Decisions?", Journal of Development Economics, Vol. 88, No. 1, pp. 1-18, doi: 10.1016/j.jdeveco.2008.02.003.

Dufey, G., Yeung, B. (1993) "The Impact of EC 92 on European Banking: A Foreign Direct Investment Perspective" Journal of Financial Management, Vol. 2, No. 3-4, pp. 11-31.

Dunning, J. H. (1988) "The Eclectic Paradigm of International Production: A Restatement and Some Possible Extensions", Journal of International Business Studies, Vol. 19, No. 1, pp. 1-31, doi: 10.1057/palgrave.jibs.8490372. 
Farazi, S., Feyen, E., Rocha, R. (2011) "Bank ownership and performance in the Middle East and North Africa Region”, World Bank Policy Research Working Paper Series 5620, doi: 10.1596/1813-9450-5620.

Focarelli, D., Pozzolo, A. F. (2001) "The patterns of cross-border bank mergers and shareholdings in OECD countries?", Journal of Banking \& Finance, Vol. 25, No. 12, pp. 2305-2337, doi: 10.1016/s0378-4266(01)00192-3.

Gassebner, M., Gaston, N., Lamla, M. (2008) "Relief for the Environment? The Importance of an Increasingly Unimportant Industrial Sector", Economic Inquiry, Vol. 46, No. 2, pp. 160-178, doi: 10.1111/j.1465-7295.2007.00086.x

Gürsoy, G., Aydoğan, K. (2002) "Equity ownership structure, risk taking, and performance", Emerging Markets Finance and Trade, Vol. 6, No. 38, pp. 6-25.

Gygli, S., Haelg, F., Sturm, J.E. (2018) The KOF Globalization Index - Revisited, KOF Working Paper, No. 439, Available at: $<$ https:/www.ethz.ch/content/dam/ ethz/specialinterest/dual/kofdam/documents/Globalization/2018/KOF_ Globalization\%20Index_Revisited.pdf>.

Havrylchyk, O. (2006) "Efficiency of the Polish banking industry: foreign versus domestic banks", Journal of Banking \& Finance, Vol. 30, No. 7, pp. 1975-1996, doi: 10.1016/j.jbankfin.2005.07.009.

Hasan, I., Marton, K. (2003) "Development and efficiency of the banking sector in a transitional economy: Hungarian experience", Journal of Banking \& Finance, Vol. 27, No. 12, pp. 2249-2271, doi: 10.1016/s0378-4266(02)00328-x.

Hermes, N., Lensink, R. (2004) "Foreign Bank Presence, Domestic Bank Performance and Financial Development", Journal of Emerging Market Finance, Vol. 3, No. 2, pp. 207-229, doi: 10.1177/097265270400300206.

Im, K.S., Pesaran, M. H., Shin, Y. (2003) "Testing for unit roots in heterogeneous panel", Journal of Econometrics, Vol. 115, No. 1, pp. 53-74, doi: 10.1016/ s0304-4076(03)00092-7.

Isik, I., Hassan, M. K. (2003) "Financial deregulation and total factor productivity change: An empirical study of Turkish commercial banks", Journal of Banking \& Finance, Vol. 27, pp. 1455-1485, doi: 10.1016/s0378-4266(02)00288-1.

Jamison, E. A., Jamison, D. T., Hanushek, E. A. (2007) "The Effects of Education Quality on Income Growth and Mortality Decline", Economics of Education Review, Vol. 26, No. 6, pp. 771-788, doi: 10.1016/j.econedurev.2007.07.001.

Jiang, R. J., Yao, S., Feng, G. (2013) "Bank ownership, privatization, and performance: Evidence from a transition country", Journal of Banking \& Finance, Vol. 37, No. 9, pp. 483-497, doi: 10.1016/j.jbankfin.2013.05.009.

Lamla, M. (2009) "Long-run determinants of pollution: a robustness analysis", Ecological Economics, Vol. 69, pp. 135-144, doi: 10.1016/j.ecolecon.2009.08.002.

Lee, E., Marco, V. (2006) "The Social Impact of Globalization in The Developing Countries", IZA Discussion Paper Series IZA DP No. 1925. Available at: $<$ http://ftp.iza.org/dp1925.pdf $>$. 
Leitao, N. C. (2011) "Foreign Direct Investment: Localization and Institutional Determinants", Management Research and Practice, Vol. 3, No. 2, pp. 1-6.

Lensink, R., Hermes, N. (2004) "The short-term effects of foreign bank entry on domestic bank behavior: does economic development matter?", Journal of Banking \& Finance, Vol. 28, No.3, pp. 553-68, doi: 10.1016/s0378-4266(02) 00393-x.

Levin, A., C.F. Lin, C. F., Chu, C.S.J. (2002) "Unit root tests in panel data: Asymptotic and finite-sample properties", Journal of Econometrics, Vol. 108, No. 1, pp. 1-24, doi: 10.1016/s0304-4076(01)00098-7.

Maddala, G.S., Wu, S.A. (1999) "Comparative study of unit root tests with panel data and a new simple test", Oxford Bulletin of Economics and Statistics, Vol. 61, No. s1, pp. 631-652, doi: 10.1111/1468-0084.61.s1.13.

Mahmutović, H., Talović, S., Kurtović, S. (2017) "Impact of globalization on the performance of the company: the case of companies from Bosnia and Herzegovina", Human, Vol. 7, No. 1, pp. 40-49.

Megginson L. W. (2005) "The economics of bank privatization”, Journal of Banking \& Finance, Vol. 29, pp. 1931-1980, doi: 10.1016/j.jbankfin.2005.03.005.

Micco, A., Panizza, U., Yanez, M. (2007) "Bank ownership and performance: Does politics matter?”, Journal of Banking \& Finance, Vol. 31, No. 1, pp. 219-241, doi: 10.1016/j.jbankfin.2006.02.007.

Pehnelt, G. (2007) "Globalization and Inflation in OECD Countries" Jena Economic Papers, number 2007-055, Available at: <https://zs.thulb.uni-jena.de/servlets/ MCRFileNodeServlet/jportal_derivate_00045848/wp_2007_055.pdf $>$.

Potrafke, N. (2015) "The Evidence on Globalisation", The World Economy, Vol. 38, No. 3, pp. 509-552, doi: 10.1111/twec.12174.

Rahman, N. A. A., Reja, B. A. F. (2015) "Ownership structure and bank performance", Journal of Economics, Business and Management, Vol. 3, No. 5, pp. 483-488, doi: 10.7763/joebm.2015.v3.232.

Rao, B. B., Tamazian, A., Vadlamannati, K. C. (2011) "Growth effects of a comprehensive measure of globalization with country specific time series data", Applied Economics, Vol. 43, pp. 551-568, doi: 10.1080/00036840802534476.

Rao, B. B., Vadlamannati, K. C. (2011) "Globalization and Growth in The Low Income African Countries with The Extreme Bounds Analysis", Economic Modelling, Vol. 28, No. 3, pp. 795-805, doi: 10.1016/j.econmod.2010.10.009.

Shaban, M., James, G. A. (2018) "The effects of ownership change on bank performance and risk exposure: Evidence from Indonesia", Journal of Banking \& Finance, Vol. 88, 483-497, doi: 10.1016/j.jbankfin.2017.02.002.

Sufian, F. (2012) "Globalization and financial sector's net interest margins: do specialization and ownership make a difference?", The Services Industries Journal, Vol. 32, No. 16, pp. 2641-2675, doi: 10.1080/02642069.2011.594877. 
Sufian, F., Habibullah, M.S. (2011) "Navigating the impact of globalization on bank efficiency in China", China \& World Economy, Vol. 19, No. 5, pp. 85-101, doi: 10.1111/j.1749-124x.2011.01260.x.

Sufian, F., Habibullah, M.S. (2012) "Globalizations and bank performance in China", Research in International Business and Finance, Vol. 2, No. 2, pp. 221-239, doi: 10.1016/j.ribaf.2011.12.005.

Sufian, F., Kamarudin, F. (2016) "The impact of globalization on the performance of Banks in South Africa", Review of International Business and Strategy, Vol. 26, No. 4, pp. 517-542, doi: 10.1108/ribs-02-2016-0003.

Thi, N. A. V., Vencappa, D. (2008) "Does the Entry Mode of Foreign Banks Matter for Bank Efficiency? Evidence from Czech Republic, Hungary, and Poland", William Davidson Institute Working Paper No. 925, doi: 10.2139/ssrn.968348.

Thoumrungroje, A., Tansuhaj, P. (2007) "Globalization effects and firm performance", Journal of International Business Research, Vol. 6, No. 2, pp. 43-58.

Tsai, M. C. (2007) “Does Globalization Affect Human Well-Being?", Social Indicators Research, Vol. 81, No. 1, pp. 103-126, doi: 10.1007/s11205-006-0017-8.

Tschoegl, A.E. (1987) "International Retail Banking as a Strategy: An Assessment", Journal of International Business Studies, Vol. 19, No. 2, pp. 67-88, doi: 10.1057/palgrave.jibs.8490407.

Tschoegl, A. E. (2002) "FDI and internationalization: evidence from U.S. subsidiaries of foreign banks", Journal of International Business Studies, Vol. 33, No. 4, pp. 805-815, doi: 10.1057/palgrave.jibs.8491045.

Tschoegl, A. E. (2003) "Financial Crises and the Presence of Foreign Banks", Wharton Financial Institutions Center Working Paper 03-35.

Vinig, T., De Kluijver, J. (2007) "Does globalization impact entrepreneurship? comparative study of country level indicators", Sprouts: Working Papers on Information Systems, Vol 7, No. 8, University of Amsterdam, Netherlands, Available at: $<$ http://citeseerx.ist.psu.edu/viewdoc/download?doi=10.1.1.553.3 $616 \&$ rep $=$ rep $1 \&$ type $=$ pdf $>$.

Zaim, O. (1995) "The effect of financial liberalization on the efficiency of Turkish commercial banks", Applied Financial Economics, Vol. 5, No. 4, pp. 257-264, doi: 10.1080/758536876.

Zhang, X., Daly, K. (2014) "The Impact of Bank-Specific and Macroeconomic Factors on China's Bank Performance", Chinese Economy, Vol. 47, No. 5-6, pp. 5-28, doi: 10.2753/CES1097-1475470501.

Zhu, W., Yang, J. (2016) "State ownership, cross-border acquisition, and risktaking: evidence from China's banking industry", Journal of Banking \& Finance, Vol. 71, pp. 133-153, doi: 10.1016/j.jbankfin.2016.05.004. 


\title{
Učinci profitabilnosti financijske globalizacije u bankarskoj industriji $\mathrm{s}$ tržištima u nastajanju: uvid $\mathrm{u}$ Tursku
}

\author{
Ece C. Akdoğan ${ }^{1}$, Ekin Ayşe Özşuca ${ }^{2}$
}

\begin{abstract}
Sažetak
Intenzivna financijska liberalizacija praćena ubrzanjem financijske globalizacije dovela je do značajnih strukturnih promjena u financijskom sektoru. S obzirom da financijske institucije igraju dominantnu ulogu u funkcioniranju financijskog sektora, osobito na tržištima u nastajanju, gdje među najosjetljivije sektore na povećanu međusobnu povezanost financijskih tržišta spada bankarska industrija, ključno je pitanje, kako financijska globalizacija zapravo utječe na učinkovitost financijskog posredovanja. Međutim, iako postoji mnogo istraživanja o financijskoj integraciji, utjecaji financijske globalizacije su neistraženo područje. Stoga, ova studija istražuje utjecaj financijske globalizacije na bankovnu profitabilnost fokusiranjem na tržišta u nastajanju, Tursku i na otkrivanju mogućih potencijalnih razlika među bankama s različitim vlasničkim strukturama. Rezultati istraživanja pokazuju da se profitabilnost temeljena na tržišnim mjerama poboljšava s financijskom globalizacijom, dok se tržište uz mjere računovodstvene profitabilnosti pogoršava jer ukazuje na pretjerani optimizam, koji zauzvrat dovodi do pogrešnih procjena problema. Osim toga, utvrđeno je da vlasnička struktura utječe na tržišne mjere gdje banke s domaćim i privatnim vlasništvima imaju više koristi. Međutim, budući da se nijedna značajna distinkcija ne može uočiti među sastavnicama vlasništva uz računovodstvene mjere profitabilnosti, takve pogrešne procjene potiču optimizam na tržištu.
\end{abstract}

Ključne riječi: financijska globalizacija, bankarska industrija, tržišna profitabilnost i računovodstvena profitabilnost, vlasnička struktura, tržišta u nastajanju

JEL klasifikacija: C23, F61, F65, G21

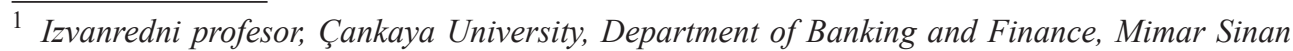
Cd. 4, 06790 Ankara, Turska. Znanstveni interes: menadžersko financiranje, financijska ekonomija i procjena imovine. Tel.: +90 31223312 04. Fax: +90 31223310 29. E-mail: ece@cankaya.edu.tr.

2 Docent, Çankaya University, Department of International Trade, Mimar Sinan Cd. 4, 06790 Ankara, Turska. Znanstveni interes: financijske institucije, makroekonomska teorija $i$ monetarna politika Tel.: +90 31223312 14. Fax: +90 31223310 29. E-mail: aozsuca@ cankaya.edu.tr (osoba za kontakt). 